\author{
공단량체의 종류 및 조성이 지글러-나타 중합된 이중 분지량 분포 고밀도 \\ 폴리에틸렌의 물성에 미치는 영향 \\ Weijuan Meng ${ }^{\dagger, \dagger}$, Hongbo $\mathrm{Li}^{\ddagger}$, Jianwei $\mathrm{Li}^{*, \dagger}$, and Biaohua Chen ${ }^{\dagger}$ \\ ${ }^{\dagger}$ State Key Laboratory of Chemical Resource Engineering, Beijing University of Chemical Technology, Beijing, China \\ YYanshan Branch, Beijing Research Institute of Chemical Industry, SINOPEC, Beijing, China \\ (접수 2011. 5. 10; 수정 2011. 6. 13; 게재확정 2011. 6. 22)

\section{The Effect of Comonomer Type and Content on the Properties of Ziegler-Natta Bimodal High-Density Polyethylene} \\ Weijuan Meng ${ }^{\dagger, \dagger}$, Hongbo $\mathrm{Li}^{\ddagger}$, Jianwei $\mathrm{Li}^{*, \dagger}$, and Biaohua Chen ${ }^{\dagger}$ \\ ${ }^{\dagger}$ State Key Laboratory of Chemical Resource Engineering, Beijing University of Chemical Technology, Beijing, China \\ $\checkmark$ Yanshan Branch, Beijing Research Institute of Chemical Industry, SINOPEC, Beijing, China. \\ ${ }^{*}$ E-mail:lijw@mail.buct.edu.cn
}

(Received May 10, 2011; Revised June 13, 2011; Accepted June 22, 2011)

\begin{abstract}
요 약. 지글러-나타 촉매를 사용하여 에틸렌을 중합함으로써 다양한 공단량체의 종류와 조성을 갖는 이중 분자량 분포 의 고밀도 폴리에틸렌이 합성되었다. 이들의 구조와 물성을 GPC, NMR, DSC, 인장 측정기를 이용하여 연구하였다. 에틸 렌/1-헥센 공중합체가 에틸렌/1-부텐 공중합체보다 비슷한 조성을 가질 경우 높은 인장강도와 파단연신율을 가짐을 확인 하였다. 분자량은 고분자의 공단량체 비율이 증가할수록 감소하였다. 짧은 곁사슬은 결정화도에 영향을 주어 결과적으로 이중 분자량 분포를 갖는 고밀도 폴리에틸렌의 모폴로지와 기계적 물성에 영향을 미쳤다. SSA로 처리 후 다수의 발열 곡 선이 관찰되었으며 이는 주로 에틸렌 배열길이와 라멜라 두께의 불균일성에 기인한다. 분포지수의 차이로부터 공단량체 의 조성이 높은 폴리에틸렌의 SCB 분포가 균일도를 향상시킴을 알 수 있었다.

주제어: 이중 분자량 분포 고밀도 폴리에틸렌, 짧은 곁사슬, 구조, 기계적 물성
\end{abstract}

\begin{abstract}
Bimodal high-density polyethylenes with different comonomer type and content were synthesized by polymerization of ethylene using Ziegler-Natta catalyst. Their structure and properties were studied using GPC, NMR, DSC and tensile test. It was found that ethylene/1-hexene copolymer exhibits higher tensile strength and elongation at break than that of ethylene/ 1-butylene copolymer with similar comonomer content. The molecular weight decreases as the comonomer content of the polymer increases. Short chain branching affects the crystallinity and thus the morphology and consequently the mechanical properties of the corresponding bimodal high-density polyethylenes. After SSA treated, the multiple endothermic peaks were observed. Multiple endothermic peaks are mainly attributed to the heterogeneity of ethylene sequence length and lamellar thickness. The difference of broadness index indicates that SCB distribution of polyethylene containing higher comonomer content has improved uniformity.
\end{abstract}

Keywords: Bimodal high-density polyethylene, Short chain branching, Structure, Mechanical Properties

\section{INTRODUCTION}

Copolymers of ethylene with other á-olefins are important products with favorable properties in comparison to homopolyethylene. Therefore, there has been a continuing interest in these polymers. In general, the physical properties of ethylene/ $\alpha$-olefin copolymers depend on a set of different variables, for example, molecular weight (MW) and molecular structure. Introduction of $\alpha$-olefin comonomer to the polyethylene chain changes the molecular structure, and consequently the properties of the poly- mer product obtained. ${ }^{1,2}$ The presence of short branches disturbs the crystallization kinetics, giving rise to copolymers with different properties. Short chain branching (SCB) polyethylene produced by ethylene copolymerization with $\alpha$-olefin comonomer, such as 1-butene and 1hexene using Z-N catalyst exhibits inhomogeneity in molecular weight distribution and branching distribution. The content and distribution of SCB result in differences in the thermal and mechanical properties. ${ }^{3}$

Simanke $e^{4}$ studied the influences of the type and concentration of $\alpha$-olefin (1-hexene, 1-octene, 1-decene, 1- 
octadecene, 4-methyl-1-pentene) on the mechanical behavior and crystallinity of some ethylene/ $\alpha$-olefin copolymers obtained by metallocene catalyst. Pankaj ${ }^{5}$ investigated the short chain branch length on the physical properties of copolymers of ethylene/1-butene, ethylene/1-hexene and ethylene/1-octene synthesized by a single site metallocene catalyst. However, no bimodal high density polyethylene (HDPE) resins based on 1-butene, 1-hexene produced using Ziegler - Natta (Z-N) heterogeneous catalyst were studied.

In this study, two bimodal HDPE resins based on 1butene, 1-hexene that have been synthesized in a multistep cascaded process using supported Z-N catalyst, were examined to specifically investigate the effect of the comonomer type on mechanical properties. We also have produced three bimodal HDPE with different 1-hexene content to investigate the effect of the comonomer content on crystallization behavior, mechanical and microstructural properties of polymer, two of which was used to study the distribution of short chain branching and lamellar thickness by successive self-nucleation/annealing (SSA) thermal fractionation technique.

\section{EXPERIMENTAL}

\section{Materials}

Polymerization-grade ethylene, hexane, triethyl aluminium (TEA) solution $(0.1 \mathrm{~mol} / \mathrm{L})$ in hexane and Z-N catalyst $[\mathrm{TiCl} / \mathrm{MgCl} 2, \mathrm{w}(\mathrm{Ti})=4.5 \%]$ were obtained from Yanshan Petrol-chemical Company (SINOPEC, China). Ethylene ( $99.5 \%$, purity) and hexane were dried on a column of $4 \AA$ molecular sieves. All other chemicals were obtained commercially and used as received.

\section{Preparation of samples}

Bimodal HDPE was synthesized in a batch mode in a $5 \mathrm{~L}$ stainless steel reactor. The reactor was equipped with a magnetic coupled stirrer with variable stirring speed and with an external jacket heater that kept the temperature constant.

Before each experiment the reactor was checked for any leakage. The reactor was heated above $90{ }^{\circ} \mathrm{C}$ and repeatedly pressurized with nitrogen, purged and evacuated $(<1.0 \mathrm{~Pa})$. Then cooling the reactor to ambient temperature and $3 \mathrm{~L}$ hexane and a prescribed amount of TEA and Z-N catalyst were injected in it. Polymerizations performed at $0.6 \mathrm{MPa}$ and $85^{\circ} \mathrm{C}$. Ethylene was polymerized in the presence of abounding hydrogen to make a homopolymer with a low MW. After homopolymerization, hexane and fines dissolved in the hexane were squeezed out by a device with a 200 mesh at $60{ }^{\circ} \mathrm{C}$, and the resulting wet polymer was dried by hot nitrogen gas flow. The gas copolymerization reaction was started with less hydrogen and optionally 1-butylene or 1-hexene to make a copolymer with a high MW. The temperature was maintained at $80^{\circ} \mathrm{C}$ and the reactor pressure was maintained at $0.25 \mathrm{MPa}$. The amount of ethylene reacted in homopolymerization and copolymerization was equal. At the end of the polymerization, purging the gas mixture and evacuation of the reactor stops the polymerization reaction. The reactor was rinsed with nitrogen for a couple of times, cooled down and opened. The product of polymer was collected and dried under vacuum.

\section{Characterization}

1-Hexene or 1-butene content in ethylene copolymer was analyzed by ${ }^{13} \mathrm{C}$ NMR (nuclear magnetic resonance spectrometer). ${ }^{13} \mathrm{C}$ NMR analysis was performed on Brucker AM-400 operating at $120^{\circ} \mathrm{C}$ and $75 \mathrm{MHz}$. The solutions of polymer were prepared in o-dichlorobenzene in a sample tube with diameter of $5 \mathrm{~mm}$. The deuterated solvent was used to provide the internal lock signal. The chemical shifts were referenced internally to methylene carbon of main chain backbone resonance, which was taken as $\delta$ 30.00 from $\mathrm{Me}_{4} \mathrm{Si}$. The spectra were taken with a $45^{\circ}$ flip angle, an acquisition time of $0.983 \mathrm{~s}$, and a delay of $3.0 \mathrm{~s}$.

Tensile properties were measured at room temperature with an Instrom universal tensile tester (Model 1175) in accordance with the GB/T 1040 II test. The average molecular weights and molecular weight distributions were determined in a high temperature Waters 220 gel permeation chromatograph (GPC). The flow rate was $1.0 \mathrm{~mL} / \mathrm{min}$, 1,2,4-trichlorobenzene was used as the eluting solvent, and the instrument was performed at $140{ }^{\circ} \mathrm{C}$.

The melting point $(\mathrm{Tm})$ and the crystallinity of polymers were determined by differential scanning calorimetry (DSC) using a DSC 7A (Perkin-Elmer) operating at a heating rate of $10^{\circ} \mathrm{C} / \mathrm{min}$ from the ambient temperature to $190^{\circ} \mathrm{C}$, and $\mathrm{Tm}$ was determined in the second scan. From the resultant endothermic curve, the heat of fusion $\left(\mathrm{H}_{\mathrm{f}}\right)$ was obtained, and the crystallinity percentage of the polymer was calculated with the following relation:

$$
\text { Crystallinity }=\left(\Delta H_{\mathrm{f}} / \Delta H_{\mathrm{f}}\right) \times 100 \%
$$

where $\Delta \mathrm{H} * \mathrm{f}$ is the heat of fusion of completely crystalline polyethylene samples (i.e., $286 \mathrm{~J} / \mathrm{g}$ ).

The component heterogeneity of ethylene/1-hexene copolymers was analyzed by SSA. The process is described 
as follows:

1. The sample was heated to $170{ }^{\circ} \mathrm{C}$ and maintained at that temperature for $5 \mathrm{~min}$ to eliminate the thermal history.

2. The sample was cooled to $30^{\circ} \mathrm{C}$ to create the socalled initial "standard" state.

3. The sample was heated to a selected thermal treatment temperature $\left(T_{S}\right)$ located in the final melting temperature range of initial "standard" state and held at that temperature for $5 \mathrm{~min}$.

4. The sample was cooled to $30{ }^{\circ} \mathrm{C}$ again, during this cooling the initially molten fraction of the polymer at $T \mathrm{~s}$ will crystallize during cooling using the unmelted crystal fragments produced in step 3 as self-nuclei.

5. The sample was heated once again at $10{ }^{\circ} \mathrm{C} / \mathrm{min}$, but this time up to a $T \mathrm{~s}$ temperature which was $5{ }^{\circ} \mathrm{C}$ lower than the previous $T \mathrm{~s}$ and held at that temperature for $5 \mathrm{~min}$.

6. Steps 4 and 5 are repeated at increasingly lower $T \mathrm{~s}$ : The differences in $T \mathrm{~s}$ were always kept constant at $5{ }^{\circ} \mathrm{C}$. The number of repetitions can be chosen to cover the entire melting range of the sample with a 'standard' thermal history or a shorter range.

7. The sample was heated to $170{ }^{\circ} \mathrm{C}$ at the rate of $10^{\circ} \mathrm{C} /$ min, after which the effects of SSA cycles would be reflected.

\section{RESULTS AND DISCUSSION}

\section{Effect of comonomer type on the properties of samples}

In order to investigate the effect of comonomer type on the mechanical properties of ethylene copolymer, two bimodal HDPE samples that had similar comonomer con-

Table 1. Tensile tested results of different samples

\begin{tabular}{lcc}
\hline Sample ${ }^{\mathrm{a}} \mathrm{No}$ & 1 & 2 \\
\hline Comonomer type & 1-hexene & 1-butene \\
Comonomer content (mol\%) & $0.80 \%$ & $0.76 \%$ \\
Crystallinity (\%) & 62.0 & 63.2 \\
Density $\left(\mathrm{g} \cdot \mathrm{cm}^{-3}\right.$ ) & 0.9368 & 0.9460 \\
Tensile strength at yield (Mpa) & 17.8 & 23.2 \\
Tensile strength at break (Mpa) & 26.5 & 23.7 \\
Elongation at break (\%) & 640 & 490
\end{tabular}

Polymerization conditions: [Ti] $=0.08 \mathrm{mmol} / \mathrm{l}, \mathrm{Al} / \mathrm{Ti}=75$, stirring rate $=300 \mathrm{rpm}$. tent but different comonomer type were synthesized. The comonomer content and tensile properties of the obtained samples were listed in Table 1.

As can be seen in Table 1, the comonomer content of the two samples is nearly identical $(0.80$ and $0.76 \mathrm{~mol} \%$, respectively). Introduction of longer $\alpha$-olefin to the polyethylene chain leads to decreased chain regularity, and in consequence to lower crystallinity and density. As a result, for similar comonomer content, the 1-hexene based polyethylene has lower crystallinity and density in comparison to the 1-butene based polyethylene. The break strength and \% elongation of 1 -hexene based resin is higher than the corresponding 1-butene based resin. It was suggested that the longer short chain branches lead to a larger fraction of tie molecules in the interlamellar region that causes the observed increase in tensile strength at break and elongation at break. It was also observed that the yield strength was higher for the 1-butene based resin than the 1-hexene based resin. This reflects the decreased crystallinity with increasing short chain branch length.

\section{Effect of comonomer content on the crystallization behavior of ethylene/1-hexene copolymers}

It is generally accepted that the methyl branches are included in the crystalline lattice, but branches higher than methyl are not able to enter the crystalline phase, creating a thin interphase inside the amorphous domain. This intermediary region presents some organization and some crystallinity. The tendency for segregation of short branches depends on their size, and the interfacial layer is extended with an increase in the contents of short branches. ${ }^{6,7}$

For the purpose of studying the effect of comonomer content on crystallization behavior of ethylene copolymer, three polyethylene samples with different content of 1-hexene were synthesized. The analyzed results of DSC were summarized in Table 2.

It can be observed from Table 2 that the melting enthalpy $(\mathrm{Hm})$ decreases with increasing the content of the comonomer 1-hexene, the insertion of the á-olefin reducing both the degree of crystallization and the melting temperature of the copolymer. These results agree with the observations of literature. ${ }^{13-15}$ When the content

Table 2. Effect of the 1-hexene content on crystallization behavior of ethylene/1-hexene copolymers

\begin{tabular}{cccccc}
\hline Sample $^{\mathrm{a}}$ No & 1-Hexene content $(\mathrm{mol} \%)$ & $\Delta \mathrm{Hm}(\mathrm{J} / \mathrm{K})$ & $T_{\mathrm{c}}\left({ }^{\circ} \mathrm{C}\right)$ & $T_{\mathrm{m}}\left({ }^{\circ} \mathrm{C}\right)$ & Crystallinity $(\%)$ \\
\hline 3 & 0.43 & 180.2 & 116.7 & 132.1 & 63.0 \\
4 & 1.07 & 176.4 & 116.3 & 130.6 & 61.7 \\
5 & 1.77 & 153.3 & 116.2 & 130.3 & 53.5 \\
\hline
\end{tabular}

a Polymerization conditions: $[\mathrm{Ti}]=0.08 \mathrm{mmol} / \mathrm{l}, \mathrm{Al} / \mathrm{Ti}=75$, stirring rate $=300 \mathrm{rpm}$. 
of 1-hexene in the copolymers increased from $0.43 \%$ to $1.77 \%$, the melting enthalpy decreased by $14.9 \%$ (from 180.2 to $153.3 \mathrm{~J} / \mathrm{K})$, the crystal temperature $\left(T_{\mathrm{c}}\right)$ and melting temperature $\left(T_{\mathrm{m}}\right)$ dropped slightly (only 0.5 and $1.8^{\circ} \mathrm{C}$, respectively), and the degree of crystallization declined by $15 \%$ (from $63.0 \%$ to $53.5 \%$ ). Such low crystalline copolymer not only has excellent toughness, environmental stress crack resistance, high impact strength, tear strength and tensile strength, but also has good processability.

\section{Effect of comonomer content on the mechanical properties and microstructure of ethylene/1-hexene copolymers}

The main factor affecting the stress/strain behavior of ethylene/ $\alpha$-olefin copolymers is the degree of crystallization. In general, the higher the degree of crystallization is, the higher are the yield stress and the resistance to strain of these copolymers. Since the degree of crystallization is directly related to the comonomer content (as can be seen in Table 2, it decreases as the comonomer content increases), one might conclude that there is a strong dependence of the mechanical properties on the comonomer contents in the copolymers.

A summary of the measured tensile properties of sample 3, 4 and 5 was shown in Table 3 . The tensile strength at yield increases while decreasing the content of 1-hexene. However, the tensile strength at break increases with increasing the content of 1-hexene. It was also noticed that the sample with the highest comonomer content, such as sample 5, exhibits the highest \% elongation. This is not consistent with the observation of Shan. ${ }^{11}$ It is known that branches higher than methyl are not able to enter the crystalline phase, creating a thin interphase inside the amorphous domain. These branches form tie molecules in the amorphous region and bear the stress with the addition of strain. These tie molecules increase with increasing the comonomer content. It is these increased tie molecules that leads to the observed increase in tensile strength at

Table 3. Microstructural and mechanical properties of ethylene/1hexene resins

\begin{tabular}{lccc}
\hline Sample ${ }^{\mathrm{a}}$ No & 3 & 4 & 5 \\
\hline 1 -Hexene content (mol\%) & 0.43 & 1.07 & 1.77 \\
$\mathrm{M}_{\mathrm{w}}\left(\times 10^{-4}\right)$ & 46.2 & 42.3 & 37.68 \\
$\mathrm{M}_{\mathrm{n}}\left(\times 10^{-4}\right)$ & 2.62 & 2.40 & 2.31 \\
Tensile strength at yield (Mpa) & 20.6 & 17.6 & 15.9 \\
Tensile strength at break (Mpa) & 17.8 & 22.8 & 24.3 \\
Elongation at break (\%) & 400 & 510 & 640 \\
a Polymerization conditions: [Ti] $=0.08 \mathrm{mmol} / \mathrm{l}, \mathrm{Al} / \mathrm{Ti}=75$, stirring \\
rate = 300 rpm.
\end{tabular}

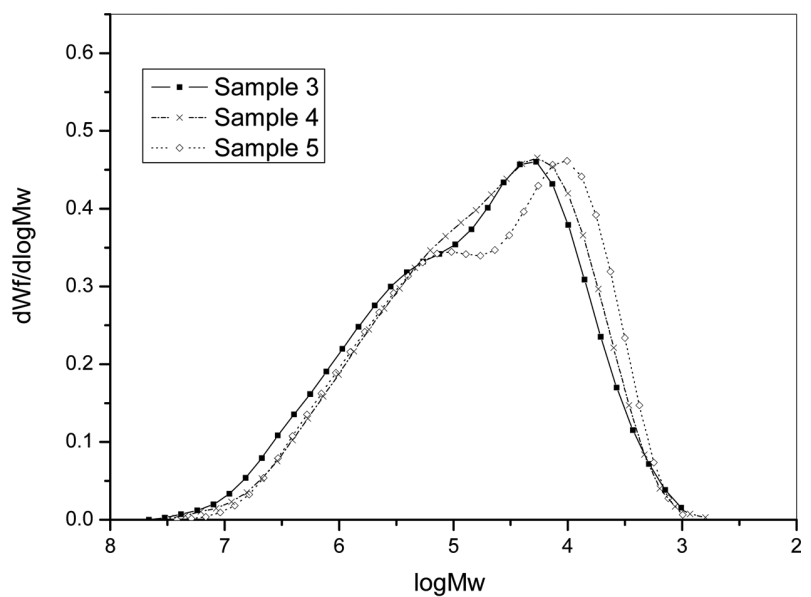

Fig. 1. Comparison of MWDs of different 1-hexene content samples.

break and elongation at break. In addition, a sample with low crystallinity possesses a large fraction of amorphous polymer. It is the slippage and disentanglement of amorphous polymer that allows it to deform and accordingly exhibits higher tensile strength at break and elongation at break.

A comparison of the corresponding molecular weight distributions (MWDs) of the three samples was shown in Fig. 1. The MWDs of the three resins are quite similar. The weight average molecular weights $(\mathrm{Mw})$ and number average molecular weights $(\mathrm{Mn})$ of the three samples were also listed in Table 3 . The weight average molecular weight decreases with the increase of comonomer content. This is due to Z-N catalyst contains many active sites. During the polymerization of ethylene and 1-hexene, a small quantity of comonomers in the polymerization feed results in some increase of the catalytic activity. For different active centers, the extent of activity increase is different when the comonomer concentration increases. The number of active centers that produce polymer with low MW increases markedly, while the number of active centers which produce polymer with high MW increases little. The resultant resin has a higher low molecular weight species and accordingly the molecular weight decreases.

\section{Component heterogeneity of ethylene/1-hexene copol-} ymers

It has been known that ethylene/ $\alpha$-olefin copolymers obtained with heterogeneous Z-N catalysts exhibit high heterogeneity in words of inter- and intra-molecular distribution of comonomer units because of the multi-side character of the catalyst. DSC has been used as a powerful method to characterize the distribution of monomer 


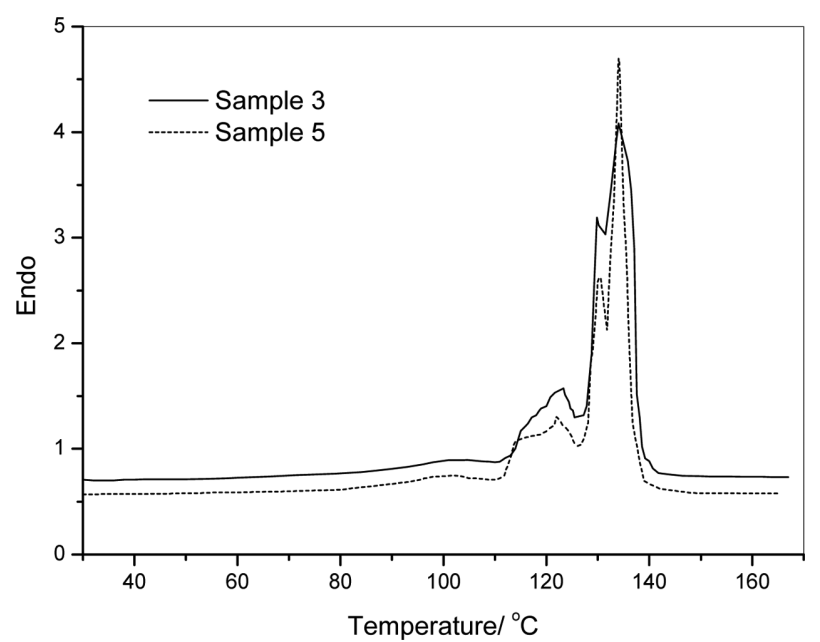

Fig. 2. SSA thermal fractionation curves of sample 3 and 5.

sequence for ethylene/ $\alpha$-olefin copolymers based on thermal fractionation. ${ }^{12-14}$ During successive self-nucleation/ annealing of the copolymer sample, polyethylene (PE) sequences of different length crystallize at different temperature to form PE lamella of different thickness. Thus the distribution of short chain branching (SCB) and lamellar thickness can be deduced by analyzing the multiple melting peaks of these lamellae in a DSC heating scan.

The SSA thermal fractionation curves of sample 3 and 5 were shown in Fig. 2. It can be seen that there is only one single endothermic peak with some shoulder peaks. The main endothermic peak represents the melting of crystals formed by ethylene homopolymerization. The multiple endothermic shoulder peaks can be mainly attributed to the lamellar thickness or ethylene sequence length (ESL) heterogeneity. The plots in Fig. 2 clearly indicate the heterogeneity existing inside bimodal branched HDPE.

Because each endothermic peak is proportional to the amount of crystals with the same stability, the differential normalized area under such fusion is proportional to the amount of lamellae that melt in the temperature interval. The lamellar thickness and ESL are related to the melting temperature, so the lamellar thickness of polyethylene can be determined by using the ThomsonGibbs equation: ${ }^{15}$

$$
L_{c}=2 \sigma_{e} T_{m}^{0} / \Delta H_{u}\left(T_{m}^{0}-T_{m}\right)
$$

where $L_{c}$ is lamellar thickness, $T_{m}$ is the observed melting point, $T_{m}^{0}$ is the equilibrium melting point of an infinitely thick polyethylene crystal $(418.6 \mathrm{~K}), \sigma_{e}$ is the surface energy of polyethylene crystal $\left(79.3 \times 10^{-3} \mathrm{~J} / \mathrm{m}^{2}\right)$, and $\Delta H_{u}$ is the enthalpy of fusion per unit volume $\left(252.6 \times 10^{6} \mathrm{~J} /\right.$ $\mathrm{m}^{3}$ ). The average ethylene sequence length (ASL) can be calculated by the following equation: ${ }^{16}$

$$
A S L=0.2534 \mathrm{X} /(1-X)
$$

where $X$ represents the $\mathrm{CH}_{2}$ mole fraction of polyethylene, which is well correlated to the melting temperature by the following equation: ${ }^{17}$

$$
-\ln \left(\mathrm{CH}_{2} \text { mole fraction }\right)=-0.331+135.5 / \mathrm{Tm}(\mathrm{K})
$$

The melting point $v s$. SCB content of the fractions obtained for our bimodal branched HDPE are correlated by the following equation: ${ }^{18}$

$$
\operatorname{Tm}\left({ }^{\circ} \mathrm{C}\right)=134-1.55 \mathrm{SCB}
$$

By use of Eqs. (2)-(5), the lamellar thickness and short chain branches distribution for the separated peaks of sample 3 and 5 obtained by the SSA thermal fractionation were calculated and presented in Tables 4 and 5, respectively. As can be seen from Tables 4 and 5, the SCB amounts for the separated peaks of sample 3 were less than those of sample 5, and about half of the polymer didn't contain comonomer. These are accordance with the polymerization process that more comonomer was added during the synthesis of sample 5 and the amount of ethylene in homopolymerization and copolymerization is equal. The sample 3 shows five peaks from $104.6{ }^{\circ} \mathrm{C}$ to $134.0^{\circ} \mathrm{C}$ corresponding to lamellar thicknesses from about $6.4 \mathrm{~nm}$ to $22.9 \mathrm{~nm}$ and average ethylene sequence length from $9.0 \mathrm{~nm}$ to $143.8 \mathrm{~nm}$. The sample 5 shows peaks at $101.8^{\circ} \mathrm{C}, 115.0{ }^{\circ} \mathrm{C}, 122.0^{\circ} \mathrm{C}, 129.1{ }^{\circ} \mathrm{C}$ and $133.6^{\circ} \mathrm{C}$, which cover lamellar thicknesses about from $6.0 \mathrm{~nm}$ to $21.1 \mathrm{~nm}$ and average ethylene sequence length from $8.2 \mathrm{~nm}$ to $126.4 \mathrm{~nm}$. The lamellar thickness and average ethylene sequence length of sample 3 are slightly larger than those

Table 4. Lamellar thickness and average ethylene sequence length distributions of sample 3

\begin{tabular}{ccccccc}
\hline Sample 3 & $\operatorname{Tm}\left({ }^{\circ} \mathrm{C}\right)$ & Percent $(\%)$ & Lamellar $(\mathrm{nm})$ & SCB (1/1000C) & $\mathrm{CH}_{2}$ mole fraction & ASL $(\mathrm{nm})$ \\
\hline 1 & 104.6 & 5.27 & 6.4 & 19.0 & 0.9727 & 9.0 \\
2 & 115.9 & 5.95 & 8.9 & 11.7 & 0.9829 & 14.6 \\
3 & 122.4 & 21.08 & 11.4 & 7.5 & 0.9886 & 21.9 \\
4 & 129.8 & 24.28 & 16.8 & 2.7 & 0.9948 & 48.3 \\
5 & 134.0 & 43.42 & 22.9 & 0.0 & 0.9982 & 143.8 \\
\hline
\end{tabular}


Table 5. Lamellar thickness and average ethylene sequence length distributions of sample 5

\begin{tabular}{ccccccc}
\hline Sample 5 & Tm $\left({ }^{\circ} \mathrm{C}\right)$ & Percent $(\%)$ & Lamellar $(\mathrm{nm})$ & SCB $(1 / 1000 \mathrm{C})$ & CH2 mole fraction & ASL $(\mathrm{nm})$ \\
\hline 1 & 101.8 & 3.52 & 6.0 & 20.8 & 0.9701 & 8.2 \\
2 & 115.0 & 6.48 & 8.6 & 12.3 & 0.9821 & 13.9 \\
3 & 122.0 & 20.46 & 11.2 & 7.7 & 0.9882 & 21.2 \\
4 & 129.1 & 14.49 & 16.1 & 3.2 & 0.9942 & 43.5 \\
5 & 133.6 & 52.05 & 21.1 & 0.0 & 0.9980 & 126.4 \\
\hline
\end{tabular}

Table 6. Lamellar thickness and SCB distributions of copolymer component within sample 3 and 5

\begin{tabular}{ccccccc}
\hline \multirow{2}{*}{ Sample } & \multicolumn{3}{c}{ Lamellar thickness distribution } & \multicolumn{3}{c}{ SCB (1/1000) distribution } \\
\cline { 2 - 7 } & $L_{n}(\mathrm{~nm})$ & $L_{w}(\mathrm{~nm})$ & $I$ & $L_{n}$ & $L_{w}$ & $I$ \\
\hline 3 & 13.0 & 14.0 & 1.08 & 6.95 & 10.37 & 1.49 \\
5 & 12.0 & 12.8 & 1.07 & 7.94 & 10.83 & 1.36 \\
\hline
\end{tabular}

of sample 5, which indicates that the higher comonomer content (sample 5) had a lower lamellar thickness and ASL, respectively.

To investigate the heterogeneity of ethylene/ $\alpha$-olefin copolymers quantitatively, Keating ${ }^{19}$ introduced statistical terms to describe the polydispersity of ethylene sequence length. Herein, the statistical terms, arithmetic mean $\bar{L}_{n}$, weighted mean $\bar{L}_{w}$, and the broadness index $I$, are also introduced and shown as follows:

$$
\begin{aligned}
& \bar{L}_{n}=\frac{S_{1} L_{1}+S_{2} L_{2}+\cdots+S_{i} L_{i}}{S_{1}+S_{2}+\ldots+S_{i}}=\sum f_{i} L_{i} \\
& \bar{L}_{w}=\frac{S_{1} L_{1}^{2}+S_{2} L_{2}^{2}+\cdots+S_{i} L_{i}^{2}}{S_{1} L_{1}+S_{2} L_{2}+\ldots+S_{i} L_{i}}=\sum f_{i} L_{i}^{2} \\
& I=\bar{L}_{w} / \bar{L}_{n}
\end{aligned}
$$

where $S i$ is the normalized peak area and $L i$ is the lamellar thickness or SCB. After deriving the melting temperature and normalized peak area of multiple endothermic peaks (as described in Table 4 and 5), with the Eqs. (6)-(8), the broadness indexes of SCB and lamellar thickness of copolymer component in sample 3 and 5 are given in Table 6. It can be seen from Table 6 that the broadness indexes of SCB and lamellar thickness of copolymer component in sample 3 are less than those of the sample 5, which suggests that sample 5 has less heterogeneity of either SCB or lamellar thickness than that of the sample 3. This demonstrates that the uniformity in chemical composition distribution of copolymer can be improved by increasing the content of comonomer.

\section{CONCLUSION}

For bimodal high density polyethylene, the type and content of comonomer affect the mechanical behavior and crystallinity degree. The crystallinity degree of these copolymers is decreased with increasing the length of the short chain branch. At similar comonomer content, 1-hexene based resin has lower yield strength and higher tensile strength and elongation at break than the 1-butene based resin. The crystallinity degree and melting point of the ethylene/ $\alpha$-olefin copolymers decrease as the comonomer content increases. The copolymer with higher comonomer content exhibits higher tensile strength at break and elongation at break. The weight average molecular weight of the polymer decreases as the comonomer content of the polymer increases.

By SSA thermal fractionation, the multiple melting peaks of bimodal HDPE copolymer are presented. The lamellar thickness and average ethylene sequence length of polymer with higher comonomer content are larger than those of the polymer with lower comonomer content. The broadness index of either SCB or lamellar thickness of copolymer component in polymer with higher comonomer content is smaller than that of the polymer with lower comonomer content, which indicates that SCB distribution of polyethylene containing higher comonomer content has improved uniformity.

\section{REFERENCES}

1. Marzena, B.; Krystyna, C.; Beata, S. M. Thermochim. Acta. 2005, 429, 149.

2. Bruni, C.; Pracella, M.; Masi, F.; Menconi, F.; Ciardelli, F. Polym. Int. 1994, 33, 279.

3. Gabriel, C.; Lilge, D. Polymer 2001, 42, 297.

4. Simanke, A. G.; Galland, G. B.; Baumhardt, N. R.; Quijada, R.; Mauler, R. S. J. Appl. Polym. Sci. 1999, 74, 1194.

5. Pankaj, G.; Garth, L.W.; Ashish, M. S.; Rajendra, K. K.; Mark, J. L.; Stephen, M. W.; Chung, C. T.; Paul, J. D. Polymer 2005, 46, 8819 . 
6. Minick, J.; Moet, A.; Hiltner, A.; Baer, E.; Chum, S. P. J. Appl. Polym. Sci. 1995, 58, 1371.

7. Glotin, M.; Mandelkern, L. Colloid Polym. Sci. 1982, 260, 182.

8. Quijada, R.; Dupont, J.; Miranda, M. S. L.; Galland, G. B. Macromol. Chem. Phys. 1995, 196, 3991.

9. Quijada, R.; Scipioni, R. B.; Mauler, R. S.; Galland, G. B.; Miranda, M. S. L. Polym. Bull. 1995, 35, 299.

10. Mauler, R. S.; Galland, G. B.; Scipioni, R. B.; Quijada, R. Polym. Bull. 1996, 37, 469.

11. Shan, C. L. P.; Soares, J. B. P.; Penlidis, A. Polymer 2002, 43, 767.

12. Kong, J.; Fan, X. D.; Xie, Y. C.; Qiao, W. Q. J. Appl. Polym. Sci. 2004, 94, 1710.
13. Starck, P. Polym. Int. 1996, 40, 111.

14. Arnal, M. L.; Balsamo, V.; Ronca, G.; Sanchez, A.; Muller, A. J.; Canizales, E.; Urbina De Navarro, C. J. Therm. Anal. Calorim. 2000, 59, 451.

15. Darras, O.; Seguela, R. Polymer 1993, 34, 2946.

16. Zhang, F. J.; Liu, J. P.; Fu, Q.; Huang, H. Y.; Hu, Z. H. J.; Yao, S. H.; Cai, X. Y.; He, T. B. J. Polym. Sci. Polym. Phys. 2002, 40, 813.

17. Keating, M.; Lee, I. H.; Wong, C. S. Thermochim. Acta 1996, 284, 47.

18. Song, S. J.; Feng, J. C.; Wu, P. Y.; Yang, Y. L.; Qiao, J. L. Chinese Polym. Bull. 2008, 3, 15.

19. Keating, M.; McCord, E. E. Thermochim. Acta 1994, 243, 129. 